\title{
Ghosts; or the Postmodern and the Posthumous
}

\author{
Thomas Docherty \\ University of Kent. Canterbury
}

Posthumous people have too many alibis to be satisfied with simple truths (Massimo Cacciari)

I

This paper might have been entitled "further reflections on the prefix "post-"; for in it, I want to consider an odd notion of the 'belated futurity'-Lyotard's 'future anteriority'-inscribed in the word; I want to explore the notion of the posthumous within postmodernism. ${ }^{1}$ In opening, and to stress that there will be a political dimension to this ostensibly aesthetic matter, I shall cite Marx, from the opening of his Eighteenth Brumaire of Louis Bonaparte. There, in the second paragraph, Marx invokes the dead:

Men make their own history, but they do not make it just as they please; they do not make it under circumstances chosen by themselves, but under given circumstances directly encountered and given from the past. The tradition of all the generations of the dead weighs like a nightmare on the brain of the living. ... (9)

Here, and not for the first time, Marx writes history as ghost story. In this piece, I will not simply rehearse Derrida's reading of Marx as ghostly in his Spectres de Marx; rather, I shall explore the relation of the ghostly to the postmodern. The great presiding question is whether there is, fundamentally, any difference between the postmodern and the modern; or whether the ghosts of modernism so linger within the postmodern that we-postmoderns - make our own histories, but under traditions so strongly inherited from the past that they stop us from attaining any true autonomy, or even any significant distinction from modernity. That is to say, the question for this paper is not so much the question that has always, oddly, dominated the postmodern-'is it over?'; but rather the question that is all the more pressing: 'have we ever been—indeed, can we ever be-postmodern; or, has it ever begun?'

Marx opens the Eighteenth Brumaire, famously, with the observation that "Hegel remarks somewhere that all the events and personalities of great importance in world history occur, as it were, twice. He forgot to add: the first time as tragedy, the second as farce" (9). That Marxian thinking persists in our own contemporary considerations of postmodernism. Jameson, for the most obvious example, sees one of the great determining characteristics of postmodernism as its substitution of pastiche for parody. All texts are, as it were, 'haunted' by the texts of the past on which they are parasitic or whose ghostly shadow makes itself

\footnotetext{
${ }^{1}$ See Jean-Francois Lyotard, The Postmodern Condition (trans. Geoff Bennington and Brian Massumi; Manchester: MUP, 1984), especially the appended essay 'Answering the Question: What is Postmodernism?'
} 
visible in the supposedly 'new' text, we can all agree. In the texts of modernism, according to Jameson, the 'incorporation' of such texts is operated in the mode of parody: Joyce cites or alludes to Homer for a purpose (perhaps to imply a comparison between the ancient world and the modern, say); or Stravinsky alludes to Mahler for a functional reason (to relate aestheticism to barbarism, say). On the other hand, in the texts of postmodernism, allusion is played with for no ulterior or instrumental motive at all: it is just the substance of our texts; so, for example, popular music is dominated by 'sampling,' or Angela Carter alludes to fairy-tales because, well, because she does so. Pastiche, according to Jameson, is a parody that has lost its purchase on the real; and in this regard, his view of the relation between the modern and the postmodern itself repeats the allegedly Hegelian trope modified by Marx, in which the tragic of the real becomes the farce of illusion or vacuity. The resulting 'waning of affect' that Jameson discovers in the postmodern is, in fact, a sense that the postmodern has lost touch with or even interest in a self-sufficient ontological reality; and the consequence of this, in turn, is that art begins to look somewhat aestheticist, vacuous, concerned with self-regarding or narcissistic form at the expense of content or of reference to a world of material history that might exist independently of our representations of it. The content of the text, such as it is, is now there only as a kind of ghostly or spectral 'allusion' to the real; what we might call an allusion to an illusion ${ }^{2}$. In what follows, I want to try to think this through in terms of the presence of death in the postmodern; hence, I hope, the appropriateness of starting from Marx's own allusions to the presence of the spirit of the past, a 'presence of the past', itself reminiscent of Paolo Portoghesi's definition of the architectural postmodern, in which the dead return, in some kind of elegiac apophrades, to haunt and burden or shadow the living.

Marx's opening gambit for the Eighteenth Brumaire is one that raises the issue of autonomy; and, for modernity, this question has been confounded with another, the question concerning authenticity. To be fully autonomous, to 'give oneself the law,' or to act according to laws that have a legitimacy not because they have been inherited from the past (legalism), but rather because they have been under-written intimately by a self-present subject, a 'here-now,' has been one of the great questions concerning modernity and modernism. We cannot be living authentically, the argument goes, if we are simply rehearsing, reiterating or acting in conformity with laws that have been established by others and that have fully determined our being. We cannot be 'real' if we are simply fulfilling a prophecy, so to speak. In sociological modernity, can we make a break from our immediate past, such as to be sure that the choices that we make, the ways that we live, have been freely chosen? In modernist aesthetics, by analogy, can the artist genuinely respond to the Poundian cry to 'make it new'? In philosophy, of course, we have come to know this as a Heideggerian question, that of Dasein, which Heidegger also identifies partly through a 'being-towardsdeath.' For Heidegger, authentic Dasein, Dasein that has attained something of autonomy and the ability to inaugurate, authorise, or initiate its own living, always looks ahead to-even runs ahead to-its death.

\footnotetext{
${ }^{2}$ For a fuller understanding of Jameson's complex relations to the postmodern, see Fredric Jameson, Postmodernism (London: Verso, 1994).
} 
We can begin to consider the great modern questions of freedom and autonomy, that is, the desire to be responsible for the immediate future, from the simple observation that there is something 'deictical' about the notion of the modern. To be modern is, in a sense, to be located in the 'now'; but the now, the contemporary, is always necessarily shifting. The single most obvious consequence of this, and of modernism's interest in the 'now,' is the loss of a particular notion of truth. ${ }^{3}$ Truth as 'transpositional'- that is to say, a truth that can be held to be true regardless of its speaker and regardless of where and when it is spoken-becomes problematic. The modernist simply cannot write that 'It is a truth universally acknowledged that a man in possession of a good fortune must be in want of a wife.' Rather, the modernist acts as Pilate: 'we both have truths; are mine the same as yours?' Modernism deals with this, of course, by claiming that it has prioritised the human subject over objectivity. It prioritises the life of the mind, an inner temporality, a subjective spirit revealed in the monologue interieur, as opposed to the style indirect libre, which is a half way house to 'free speech.' This is the meaning of Woolf's great idea, in her attack on Wells, Bennett, Galsworthy, that life is not to be found in the world of objects outside; rather it is to be found in the myriad sensations striking an ordinary mind on an ordinary day, and all the changeableness implied in that inner, unstable, ever-shifting inner life of the mind. Indicating that 'life is not a set of gig-lamps symmetrically arranged,' she writes:

Examine for a moment an ordinary mind on an ordinary day. The mind receives a myriad impressions - trivial, fantastic, evanescent, or engraved with the sharpness of steel. From all sides they come, an incessant shower of innumerable atoms. . Let us record the atoms as they fall upon the mind in the order in which they fall, let us trace the pattern, however disconnected and incoherent in appearance, which each sight or incident scores upon the consciousness. (CR, 189-90)

This kind of approach is modernism's great defence against the loss of the real. As Levenson has argued, modernism typically subscribes to the notion, expressed here in Woolf directly, but also echoed in the writings of Ford or Conrad, that the 'real' exists only insofar as it is filtered through a consciousness; and it is the task of the novelist, having lost an objective real that can be described externally, to give us the mediations of the real instead. ${ }^{4}$ Modernism, thus, becomes a literature of the medium itself; in modernism, we might say, borrowing from McLuhan, the medium is the message, the message the medium. Yet I want this also to hold for us the obvious reverberations on the other sense of 'medium': that is, that modernism is a literature of the spirit medium, a ghost-written ouija-board literature. Prior to this, we had seen a similar kind of attempt to deal with the impending loss of the real, in the deployment of a style indirect libre: the author knows the self of a character, and thus the 'truth' of character is exterior to her. She has no freedom, but rather the appearance of freedom, the form of freedom without a content (Mme Bovary being a prime example of this).

It is thus in this interior life, this life of the present mind, with its temporal evasiveness, as in Proust, that modernism finds a version of what it will call authenticity. For modern-

\footnotetext{
${ }^{3}$ See, for a fuller exploration of this, my essay, 'Now Here This,' in Roger Luckhurst, ed., The Contemporary (London: Longman's, 1999).

${ }^{4}$ Michael Levenson, A Genealogy of Modernism (Cambridge: CUP, 1984; repr. 1986).
} 
ism, authenticity is the great escape from the demands of a transpositional truth; for if we can have no access to as truth universally acknowledged-if we have lost Kantian universals- then at least we can be somehow true to the self, 'consistent,' acting in conformity with a rule that govern the self, the rule of the self (or the rules of art, as in Bourdieu on Flaubert). ${ }^{5}$ In this, the self is always a hypothesis; and in this unfixedness, we have a sense of the existential openness of a character, as praised by writers as diverse as Sartre, Murdoch, Sarraute. Claude Mauriac. The modernist is, as it were, she or he who follows the great 'modern' advice of Polonius, 'To thine own self be true'; for the modernist, indeed, there is no other possibility. The problem that remains, however, is the fact that the self is, by definition of being 'modern,' itself constantly in flux. To what, therefore, am I being true in my modernist authenticity?

This allows me to open what is an important question at the heart of contemporary art. The idea of 'responsibility' is one that has to some extent informed our thinking about the postmodern. The detractors of the postmodern, those-especially on the political Left-who think that it is a negative or regressive moment in aesthetic history, are fond of stigmatising the postmodern as conditioned by 'irresponsibility.' They see the postmodernist as a kind of Nero, concerned with aesthetic matters (fiddling) while politics demands some real engagement (Rome burning). In contemporary theory, the rationale for the kind of 'irresponsibility' in question here is provided by the thought of Lyotard, especially in his concern that we 'judge without criteria.' I want here to explore this a little, for it has become a problematic issue for contemporary criticism. My way into this, however, will be through a further exploration of the temporal condition of the postmodern, and its relation to death.

One of the greatest thinkers on the subject of the temporal condition or predicament in which we find ourselves is Augustine, whom Lyotard describes as a 'modernist,' especially in the Confessions. I start, though, from Augustine's meditation on time in his City of God. In particular, I shall focus on Book XIII, chapter 11, in which Augustine asks 'Can one be living and dead at the same time?' In a way, of course, this is asking whether we believe in ghosts. In the passage that I will cite, we see Augustine as a great precursor of both Derrida and Beckett, whose work carries the ghostly traces of his sophisticated philosophy as well as of its style. Here is Augustine:

it seems extremely odd to say that a man is living and dying simultaneously, when he cannot be waking and sleeping at one and the same time. If so, we must try to discover when a man is dying. Now before death comes, he is not dying, but living; and when death has come, he is dead, not dying. Thus there is a period which is still before death, another which is already after death.

So when is he 'in death'? For it is then that he is dying; and so there are three situations: 'before death,' 'in death,' and 'after death,' and three corresponding adjectives: 'living,'

\footnotetext{
${ }^{5}$ See Pierre Bourdieu, The Rules of Art (trans. Susan Emanuel; Cambridge: Polity Press, 1996).
} 


\begin{abstract}
'dying,' and 'dead.' This makes it very hard to define when he is dying, that is 'in death'; a state in which he is neither living (which is the state before death) or dead (which is after death), but dying, or 'in death.' It is evident that as long as the soul is in the body, especially if sensibility remains, a man is alive, his constituent parts being soul and body. Consequently, he must be described as being still 'before death,' not 'in death.' But when the soul has departed and has withdrawn all bodily sensation, a man is said to be 'after death,' and dead.
\end{abstract}

Thus between these two situations the period in which a man is dying or 'in death' disappears. For if he is still alive, he is 'before death'; if he has stopped living, he is by now 'after death.' Therefore he is never detected in the situation of dying, or 'in death.' The same thing happens in the passage of time; we try to find the present moment, but without success, because the future changes into the past without interval. (519-20)

This is expressed in extraordinarily Derridean terms in the Confessions:

What, then, is time? I know well enough what it is, provided that nobody asks me; but if I am asked what it is and try to explain, I am baffled. All the same I can confidently say that I know that if nothing passed, there would be no past time; if nothing were going to happen, there would be no future time; and if nothing were, there would be no present time.

Of these three divisions of time, then, how can two, the past and the future, be, when the past no longer is and the future is not yet? As for the present, if it were always present and never moved on to become the past, it would not be time but eternity. If, therefore, the present is time only by reason of the fact that it moves on to become the past, how can we say that even the present $i s$, when the reason why it is is that it is not to be? In other words, we cannot rightly say what time is, except by reason of its impending state of not being. (264)

Here, we have effectively a discussion of the problem of the modern: if to be 'modern' is to be 'here-now,' then being modern is always already marked by that which is precisely present as an absence: the ghost. If, further, to be 'postmodern' is somehow to be ahead of oneself, the consequence is that the writer is somehow always already herself posthumous, always already the prefiguration of herself as a revenant, as a ghost. That is to say, there is a simple temporal shift. In modernism, I try to be in the present moment, but realise that that present moment is haunted by the past; in postmodernism, I try to be somehow in the future, and the consequence of this is that the future self becomes the 'real' self, the present becoming precisely that which will have haunted that real self in the future. The present becomes ghostly, spectral.

Commenting recently on the work of Jan Patocka, Derrida, in his Gift of Death, explicitly relates the kind of attitude to death of which we speak here with responsibility. He follows what is still a Heideggerian line according to which death is that which marks one out as absolutely singular:

Death is very much that which nobody else can undergo or confront in my place. My irreplaceability is therefore conferred, delivered, 'given,' one can say, by death. . . . It is from the site of death as the place of my irreplaceability, that is, of my singularity, that I feel called to responsibility. In this sense only a mortal can be responsible. (41)

In this, Derrida is also indirectly addressing the great modern-Marxist-question of autonomy. If autonomy consists in 'giving oneself the law' or in the kind of authenticity 
desired by Heidegger, then autonomy means that somehow we can escape determination by the ghosts - laws — of the past, and that we can inaugurate, can 'make it new,' can somehow escape the temporal bind in which I say we find ourselves. For the postmodern, this has become the vexed question of the responsibility-or answerability - of criticism. To what will my criticism answer? To the people? To emancipation? To a moral law? Against all this, as we know, Lyotard famously argued for a mode of judgement indebted to a certain understanding of both Aristotle and Kant, a 'judging without criteria.' Here is Kant:

Judgement in general is the faculty of thinking the particular as contained under the universal. If the universal (the rule, principle, or law) is given, then the judgement which subsumes the particular under it is determinant. . . . If, however, only the particular is given and the universal has to be found for it, then the judgement is simply reflective. (18)

It is, of course, art that is a primary location of reflective judgement, for there are no rules governing art or its judgement or the production of beauty. Art-and, indeed and further, criticism-is precisely the exercise of looking for those rules. That is to say, in a very strict sense, aesthetic criticism must be an enactment of a reflective judgement, a judging without criteria for judgement or evaluation, a judgement that is not responsible to any pre-existing or determining law. A postmodern, insofar as she escapes the ghost of the law that she inherits, becomes autonomous, authentic. The problem is that, given such irresponsibility, given the fact that she acts in accordance with no laws, that she is an outlaw, the postmodern authentic and autonomous subject cannot be understood.

Massimo Cacciari's work is useful in this regard. He makes a very important distinction. On the one hand, we can have the critic or artist who is 'untimely,' 'avant-garde,' somehow ahead of the present state of play in art, and therefore awaiting the arrival, at some point in the future, of an aesthetic that will understand the work. On the other hand, we can have what he calls the 'posthumous people': as he writes:

The term 'untimely' carries, however unconsciously, the possibility of becoming timely. Untimely people can always look ahead to their own time. Not so for posthumous people; they are absolutely protected from the risk of expectation. They cannot be reached, they cannot be understood. (5)

The posthumous is, as Cacciari argues, no longer responsible to her community; it is not the case that she is in advance of her time or her people. As Cacciari has it, the posthumous person is she or he who has transcended, through their very achievement of autonomy, the category of 'the people' as such. The postmodern subject, I claim, has nothing to do with 'the people.'

III

Which returns me to politics. I return, once more, to the ghost that haunts contemporary criticism: the Marx of the Eighteenth Brumaire. Here is Marx on democracy:

the democrat, because he represents the petty bourgeoisie ... imagines himself elevated above class antagonism generally. The democrats concede that a privileged class confronts them, but they, along with all the rest of the nation, form the people. What they represent is 
the people's rights; what interests them is the people's interests. Accordingly, when a struggle is impending, they do not need to examine the interests and positions of the different classes. They do not need to weigh their own resources too critically. They have merely to give the signal and the people, with all its inexhaustible resources, will fall upon the oppressors. $(50-51)$

Clearly, Marx has little time for this kind of democracy, for the simple reason that it constructs an abstract version of the people, a form of the people without any specific content. This-bourgeois democracy-is one in which I must subscribe to the notion that my 'representative' will, in fact, authentically 'represent' me. She or he must somehow embody the ghost of me, must speak - as a medium - in my voice. How, wonders Marx, can we give a content to the notion of the people? How can we more authentically embody them, or give blood to their ghosts?

In conclusion, then, we must reconsider the claims that exist for the supposed link between literature - especially postmodern literary culture - and democracy. On the one hand, there is the simplistic argument that, because the postmodern is ostensibly open to popular forms of culture and because it has ostensibly eradicated the distinctions between 'high' and 'popular' culture, it is somehow intrinsically democratic, an art for and by the people. On the other hand, postmodern culture, contaminated as it is with ideas taken from the difficulties of contemporary philosophy and from the heritage of the avant-garde, is a culture that remains somehow 'above' the masses, unavailable to those who cannot see the ironies, the aporias, the intertextual allusions, the playfulness and so on.

At the core of the argument lies a troubling link between art and philosophy with regard to their respective claims upon truth and authenticity. In his recent Petit manuel d'inesthetique, Alain Badiou proposes that the link between art and philosophy has traditionally been thought in one of three ways. ${ }^{6}$ In the first way, which he labels didactic, it is claimed that art is itself incapable of truth, while yet offering the semblance of truth; and, accordingly, the task of philosophy, in this situation, is to correct art, or to banish and censor it, or to treat it in a purely instrumental fashion. Philosophy judges art, according to determinant judgements regarding the production of truth as philosophy knows it. In the second case, which Badiou calls the romantic view, it is only art that is capable of the truths that philosophy can merely hint at, suggest or imply. Art here is a kind of incarnation or realisation of a truth that can be realised only through the medium of art and not through the discourses of an ostensibly 'ratiocinative' philosophy ('more in heaven and earth than is dreamt of in your philosophy,' as it were). The third way, the classical, accepts that art does not propose the truth, but actually feels no concern at this fact; for the classical view follows Aristotle in saying that the purpose of art is not to speak the truth but rather to be therapeutic, to make us feel better. Its domain, therefore, is not that of truth but rather that of probability and vraisemblance. These three schemes, argues Badiou, have dominated our thinking about the relation of art to philosophy; and we might say, therefore, that they have also shaped our aesthetics and fully conditioned our criticism. Badiou, predictably, says

\footnotetext{
${ }^{6}$ What follows in my text here is a much-abbreviated version of a full argument, for which the reader should see Alain Badiou, Petit manuel d'inesthetique (Paris: Seuil, 1998), chapter 1.
} 
that these three are insufficient to our case or predicament; and so he proposes that we rethink the relation between art and philosophy. I shall endorse this and propose, as my conclusion, a rethinking of the politics of a ghostly postmodern.

In the midst of all this, we can see the persistence of a relation that combines modernity with authenticity; but, troublingly, that authenticity, insofar as it is determined or shaped by autonomy, is also precisely the condition of being 'in the present' or, in Augustine's terms, 'in death.' There is thus a link, a quite remarkable intimacy and almost an identity, in fact, between authenticity and death. If we are to escape this 'ghostly' condition of the postmodern, a condition in which we simply reiterate precisely the problems-especially the political problems — of modernism, then we must address the notion of authenticity and autonomy.

In this, I take some further observations from Badiou. First, he proposes that art is itself a thought or a thinking; and it is one in which the work of art itself constitutes the reality of the thought. That is to say, art is not the reflection or mediation of a thought; but is itself the thought. Further, the truths that are activated or proposed in this 'art-thought' are 'irreducible to other truths, be they scientific, political, or amorous.' It follows from this is that art, insofar as it is a singular thought, is irreducible to philosophy. The truth that we have enacted in art is a truth given nowhere else. Additionally, it follows that art retains an educative purpose, in that it enacts truths unavailable elsewhere. Badiou claims that art educates solely for the purposes of its own existence: the purpose is to make it possible to encounter art, or, simply, 'to think a thought.' Art is that which forces us to think a thought.

Now, as Heidegger and many others have asked. 'Was ist Denken?' What is a thought? What would qualify as an act of thinking? Following Wittgenstein, the act of thinking, we might say, cannot be an entirely solitary exercise: for thought to happen, the thinker is always already radically split internally; for there can be no private language within which thinking as such could happen. The thinker thinks to herself. Let us now call the thinker the reader, for we are concerned with how it is the case that literature forces us to think as we encounter it. The reader must always be 'other than herself' in the act of reading, if it is the case that the act of reading has produced thinking; and, consequently, the very idea that she can be authentic is now called into question. ${ }^{7}$ Authenticity is what happens when the reader recognises herself or something already 'known' in the text; that is to say, when the text fails to produce thinking but simply reveals or endorses previous judgements, determinant judgements; or, and let us now call them what they are: opinions. To read in a fashion that circumvents the authenticity that is tied to death is, in fact, to become a specific kind of reader, a 'hypocrite lecteur,' such as that addressed by Baudelaire. Hypocrisy is that which makes thinking possible, insofar as this thinking is one that can have a content rather than just a form.

Let me reiterate schematically. Modernism calls truth into question, but replaces it with authenticity. Having done so, it subscribes to a view that authentic being is to be found in

\footnotetext{
${ }^{7}$ I explore this more fully in the chapter entitled 'The Ethics of Alterity,' in my recent Alterities (Oxford: OUP, 1996).
} 
particular kinds of intensity, specifically the intensity of the present moment. However, it discovers that the present moment is always haunted, not just by the ghosts of the past, but also by the fact of one's own death, one's own ghostliness. Postmodernism, such as we have understood it, further radicalises this whole loss of truth, or the degeneration of truth into authenticity, and calls this various forms of relativism, or pragmatism. Truth is "what is better in the way of belief,' as it were; and it is therefore variable, mutable. In both cases, art gradually is seen as evacuating itself of referential content. In modernism, reference becomes primarily self-referentiality (books about books, as in Gide or Proust; music about music, as in Stravinsky, then the Second Viennese School and since; paint about painting, as in Carlo Maria Mariani, and so on). In postmodernism, content has been replaced by various triumphs of form. The way of understanding this would be to consider Augustine on time. For Augustine, insofar as the present moment has any content at all, it is a content marked by death; but the understanding of the passage of time is enabled by us having the form of narrative which will link moments in time (past, present and future; or, beginning, middle and end) and thereby circumvent death. Narrative gives us the form of time (past into future, linked logically) but devoid of any present content, for the presence of content is actually the presence of death.

It follows from this schema that we should think the relation of art to politics in what are essentially formal, abstract terms. Texts, we say, at best articulate for or represent 'the people.' Yet, according to the logic of Alain Badiou, what they represent is simply 'opinion.' The question now really becomes, as Badiou puts it: "is there anything other than opinion, or, in other words ... is there any thing other than our 'democracies'?" (29) given that democracy is nothing more or less than the accounting for determinant judgements, or the expression of opinions.

For art to produce a thinking that would be a counter to opinion, we should allow for the possibility that there might be something wrong with the modernist notion of authentic being, a notion that persists throughout postmodernism, even and most especially in those postmodern works that question authentic being or satirise it most insistently. The claim of this paper is simple, finally: what is wrong with authenticity is that it is tied to death, to ghostly being, to representation; and the argument is that the only way to counter such a triumph of representation and to gain access to a real is through hypocrisy, through a form of inauthenticity that makes hypocrites lecteurs of us all.

\section{WORKS CITED}

Agustine. City of God. Trans. Henry Bettenson. London: Penguin, 1972; rpt. 1980.

. Confessions. Trans. R.S. Pine-Coffin. London: Penguin, 1961.

Badiou, Alain. Petit manuel d'inesthetique. Paris: Seuil, 1998.

Bourdieu, Pierre. The Rules of Art. Trans. Susan Emanuel. Cambridge: Polity Press, 1996.

Cacciari, Masimo. Posthumous People. Trans. Rodger Fierdman. Stanford: SUP, 1996. 
Derrida, Jacques. The Gift of Death. Trans. David Wills. Chicago: U of Chicago P, 1995.

Docherty, Thomas. "Now Here This." The Contemporary. Ed. Roger Luckhurst. London: Longman's, 1999.

Alterities. Oxford: OUP, 1996.

Jameson, Fredric. Postmodernism. London: Verso, 1994.

Kant, Immanuel. The Critique of Judgement. Trans. James Creed Meredith. Oxford: Clarendon Press, 1952.

Levenson, Michael. A Genealogy of Modernism. Cambridge: CUP, 1984; rpt. 1986.

Lyotard, Jean-François. The Postmodern Condition. Trans. Geoff Bennington and Brian Massumi. Manchester: MUP, 1984.

Marx, Karl. The Eighteenth Brumaire of Louis Bonaparte. Pekin: Foreign Languages Press, 1978. 